\title{
Pharmacodynamic Considerations with Recombinant Human Insulin-Like Growth Factor-I in Children
}

\author{
Robert J. Ferry, Jr. ${ }^{a} \quad$ Pinchas Cohen $^{\mathrm{b}}$ Lorraine E. Levitt Katz \\ ${ }^{a}$ Division of Pediatric Endocrinology and Diabetes, Departments of Pediatrics and Cellular and Structural \\ Biology, The University of Texas Health Science Center at San Antonio, Tex., USA; and 2nd Battalion, 112th \\ Armored Regiment, 36th Infantry Division, Texas Army National Guard, 56th Brigade Combat Team, Iraq; \\ ${ }^{b}$ Division of Pediatric Endocrinology, Mattel Children's Hospital and David Geffen School of Medicine, The \\ University of California, Los Angeles, Calif., and 'Division of Endocrinology and Diabetes, The Children's \\ Hospital of Philadelphia, The University of Pennsylvania, Philadelphia, Pa., USA
}

\section{Key Words}

Hyperinsulinism $\cdot$ IGF-I dosing $\cdot$ rhIGF-I dosing •

Pharmacokinetics $\cdot$ IGF-I $\cdot$ IGFBP

\begin{abstract}
Aim: To report effects of weight-based recombinant human insulin-like growth factor-I (rhIGF-I) on IGF axis parameters in children with hyperinsulinism. Methods: Open label trial with subcutaneous rhIGF-I $(40 \mu \mathrm{g} / \mathrm{kg} /$ dose). Patients studied were children (1 month to 11 years) with diffuse hyperinsulinism $(n=7)$. Serial serum IGF and insulin-like growth factor binding protein (IGFBP) concentrations were measured by RIA and analyzed by linear Pearson regression. Results: Following the initial rhIGF-I dose, total insulin-like growth factor-I (IGF-I) rose by $56 \%$ at $30 \mathrm{~min}(p<0.01)$ and $85 \%$ at $120 \mathrm{~min}(p<0.02)$. Serum IGF-II, IGFBP-2, and IGFBP-3 levels did not change. Peak serum IGF-I levels within $12 \mathrm{~h}$ of the initial rhIGF-I dose were $167-700 \mathrm{mg} / \mathrm{ml}$. The variable peak IGF-I response is attributable in part to IGFBP-3 differences across this pediatric age range. Models of rhIGF-I dosing based upon body surface area (BSA) or initial IGFBP-3 resulted in predictable peak serum IGF-I levels $(r=0.78$; $\mathrm{p}<0.03$ ). Recalculating rhIGF-I dosing based upon the
\end{abstract}

BSA - IGFBP-3 product correlated closely with peak IGF-I level $(r=0.85 ; p<0.007)$. Conclusions: Weightbased IGF-I dosing in this cohort resulted in variable IGF-I levels. Considering BSA and serum IGFBP-3 concentration in children is appropriate for subcutaneous IGF-I administration. A combination of these values may yield predictable individualization of rhIGF-I dosing.

Copyright (C) 2005 S. Karger AG, Basel

Neither the US Government nor any of their employees makes any warranty, expressed or implied, or assumes any legal liability or responsibility for the accuracy, completeness, or usefulness of any information, product, or process disclosed, or represents that its use would not infringe privately owned rights. Reference herein to any specific commercial products, process, or service by trade name, trademark manufacturer, or otherwise, does not necessarily constitute or imply its endorsement, recommendation, or favoring by the US Government. The opinions of the authors expressed herein do not necessarily state or reflect those of the US Government, and shall not be used for advertising or product endorsement purposes.

Portions of the work were presented in abstract form at the 81st Annual Meeting of The Endocrine Society held June 1999 in San Diego, Calif., USA.

\section{KARGER}

(c) 2005 S. Karger AG, Basel

Fax +41613061234 E-Mail karger@karger.ch www.karger.com www.karger.com/hre
Lorraine E. Levitt Katz, MD

Diabetes and Endocrine Division, South Tower, 8th floor, Room 8C09

The Children's Hospital of Philadelphia, 34th Street and Civic Center Blvd

Philadelphia, PA 19104-4399 (USA)

Tel. +1 215590 5338, Fax +1 267426 7063, E-Mail katzl@email.chop.edu 
Insulin-like growth factor-I (IGF-I) belongs to the relaxin/insulin family of peptide hormones and exerts major actions in carbohydrate, lipid, and protein metabolism, predominantly through activation of type 1 IGF receptors. Effects of IGFs are modulated by insulin-like growth factor binding proteins (IGFBPs), which are secreted by various cell types and found in most biological fluids [1]. Over $99 \%$ of IGF molecules in human serum circulate in a $150-\mathrm{kDa}$ ternary complex formed by an IGF molecule, IGFBP-3, and the glycoprotein known as the acid-labile subunit (ALS). Recombinant human (rh) IGF-I restores growth and improves insulin action in individuals with growth hormone insensitivity syndrome (GHIS) due to GH receptor mutations, which result in IGF-I deficiency [2-4]. Young adults and adolescents with type 1 diabetes have been shown to gain significant benefits in glycemic control during recombinant human insulin-like growth factor-I (rhIGF-I) administration [5, 6]. rhIGF-I has been used to promote protein anabolism [7-10] and to improve insulin sensitivity [11-13] across diverse clinical conditions, including starvation, AIDSassociated wasting, severe thermal burn, and extreme insulin resistance (type A).

We recently reported the first use of rhIGF-I to suppress insulin oversecretion in children with congenital hyperinsulinism (HI) due to autosomal recessive mutations of the $\beta$-cell sulfonylurea receptor (SURI) [14]. With the exception of our recent study and use of the related therapeutic IGF-I/IGFBP-3 complex in a burn population [15], clinical experience with rhIGF-I in the pediatric population has been restricted to patients with GHIS [16] or adolescents with type 1 diabetes mellitus $[17,18]$. Children suffering from catabolic burn as well as those with GHIS demonstrate abnormally low serum IGFBP-3 levels. Children with type 1 diabetes may have abnormally low serum IGFBP-3 levels, particularly when metabolic control is poor [19].

Our study presents the rare opportunity to examine the effects of rhIGF-I dosing in a pediatric population with a wide age span and normal IGFBP-3 levels. According to customary pediatric practice, all children in our trial received rhIGF-I dosed upon their body weight, specifically $40 \mu \mathrm{g} / \mathrm{kg}$ administered subcutaneously every $12 \mathrm{~h}$. The purpose of this article is to report the effects of weight-based IGF-I dosing across the prepubertal hyperinsulinism patients studied (ages 1 month to 11 years) on IGF axis parameters.

\section{Subjects and Methods}

\section{Patient Characteristics and Study Design}

The study group was recruited from children with congenital hyperinsulinism, a diagnosis confirmed by fasting hypoglycemia (serum glucose level $<50 \mathrm{mg} / \mathrm{dl}$ ) with concomitant, inadequate suppression of insulin action (insulin $>2 \mu \mathrm{IU} / \mathrm{ml}, \mathrm{C}$-peptide $>2.2 \mathrm{ng} /$ $\mathrm{ml}$ ), in the absence of pituitary or adrenal dysfunction. Children with hyperinsulinism also displayed evidence of increased insulin action when hypoglycemic at the end of a controlled fasting study. Increased insulin action was defined as increased glucose utilization, suppressed lipolysis and/or ketogenesis, and/or an inappropriate response to glucagon stimulation (i.e., a rise of serum glucose from baseline by $\geq 30 \mathrm{mg} / \mathrm{dl}$ in response to glucagon $1 \mathrm{mg}$ administered by parenteral or intramuscular injection while hypoglycemic) [20]. Additional entry criterion for this trial was suboptimal glycemic control, defined as inability to fast an age-appropriate interval (at least $6 \mathrm{~h}$ in infants or $10 \mathrm{~h}$ in children), while maintaining serum glucose levels $>60 \mathrm{mg} / \mathrm{dl}$. Exclusion criteria included suspected insulinoma, history of malignancy, age $<1$ month, hepatic or renal dysfunction, anemia, evidence of intravascular volume depletion, fever, or other evidence of acute infectious disease. The study was approved by the Institutional Review Board. All parents gave written informed consent, and all children $\geq 8$ years gave verbal or written assent. The patients' standard medical care included frequent feedings, diazoxide, octreotide, glucagon, and/or sub- to near-total (95-99\%) pancreatectomy [21, 22]. Medical treatments were continued during the study.

Children were admitted to the General Clinical Research Center under an open label protocol in which each child served as his or her control. All received a standard diet. rhIGF-I was administered as $40 \mu \mathrm{g} / \mathrm{kg} /$ dose s.c. every $12 \mathrm{~h}$ starting at 20:00 h for a maximum of three doses. Pharmacia \& Upjohn Peptide Hormones (now Pfizer, New York, N.Y., USA) generously provided rhIGF-I. The first IGF-I dose was given before an evening snack and blood was sampled hourly for IGF-I levels for $4 \mathrm{~h}$. The subjects underwent a Sustacal mixed meal tolerance test at 08:00 $\mathrm{h}$ following the second IGF-I dose. When not under study, patients received their usual meals and snacks. Patients received frequent glucose and safety monitoring at all times. Standing height was determined by the mean of triplicate measurements using a wall-mounted stadiometer (Holtain Ltd, UK). Length was determined in infants $<1$ year of age using the mean of triplicate measurements upon a recumbent stadiometer. Body surface area (BSA) was calculated by a modification of the method by Dubois and Dubois [23, 24].

$$
\operatorname{BSA}\left(\mathrm{m}^{2}\right)=\sqrt{\frac{\text { Height }(\mathrm{cm}) \cdot \text { Weight }(\mathrm{kg})}{3,600}}
$$

Assays

IGF-I, IGF-II, IGFBP-2, and IGFBP-3 levels were quantified by specific RIA (Esoterix Endocrinology, Calabasas Hills, Calif., USA). Prior to IGF RIA, serum samples were extracted with acidethanol to remove IGFBPs. These IGF-I and IGF-II RIAs demonstrate sensitivity of $20 \mathrm{ng} / \mathrm{ml}$ and negligibly cross-react with related molecules such as insulin and proinsulin. These IGFBP-2 and IGFBP-3 RIAs possess sensitivity of 5.0 and $0.3 \mathrm{ng} / \mathrm{ml}$, respectively, and do not cross-react with related molecules such as other IGFBPs. 
Table 1. Characteristics of patients with congenital hyperinsulinism

\begin{tabular}{lcllllll}
\hline Child & Age & Gender & $\begin{array}{l}\text { Weight } \\
\mathrm{kg}\end{array}$ & $\begin{array}{l}\mathrm{BSA} \\
\mathrm{m}^{2}\end{array}$ & $\begin{array}{l}\mathrm{BMI} \\
\mathrm{kg} / \mathrm{m}^{2}\end{array}$ & $\begin{array}{l}\text { Pancrea- } \\
\text { tectomy }\end{array}$ & Therapy \\
\hline 1 & 11 & $\mathrm{~F}$ & 27.6 & 1.0 & 27.6 & $95 \%$ & Frequent feeds \\
2 & 4 & $\mathrm{M}$ & 19.5 & 0.76 & 25.7 & $99 \%$ & Frequent feeds \\
3 & 8 & $\mathrm{M}$ & 35.2 & 1.2 & 29.3 & None & Frequent feeds \\
4 & 10 & $\mathrm{~F}$ & 26.1 & 0.92 & 28.4 & $95 \%$ & Frequent feeds, s.c. octreotide \\
5 & 3 & $\mathrm{M}$ & 24 & 0.85 & 28.2 & $95 \%$ & Frequent feeds, diazoxide \\
6 & $1 \mathrm{mo}$ & $\mathrm{F}$ & 7.2 & 0.37 & 19.5 & $95 \%$ & Frequent feeds, diazoxide \\
7 & 7 mo & F & 9.9 & 0.45 & 22.0 & None $^{1}$ & Frequent feeds, s.c. octreotide \\
\hline
\end{tabular}

$\mathrm{BSA}=$ Body surface area $\mathrm{BMI}=$ body mass index $\mathrm{F}=$ female; $\mathrm{M}=$ male.

${ }^{1}$ This patient required $95 \%$ pancreatectomy immediately after the study.

Table 2. IGF-IGFBP axis profiles

\begin{tabular}{llllllll}
\hline Child & Age & $\begin{array}{l}\text { BSA } \\
\mathrm{m}^{2}\end{array}$ & $\begin{array}{l}\text { Basal IGF-I } \\
\mathrm{mg} / \mathrm{l}\end{array}$ & $\begin{array}{l}\text { Peak IGF-I } \\
\mathrm{mg} / \mathrm{l}\end{array}$ & $\begin{array}{l}\text { Basal IGFBP-3 } \\
\mathrm{mg} / \mathrm{l}\end{array}$ & $\begin{array}{l}\text { Basal } \\
\text { IGF/BP-3 }\end{array}$ & $\begin{array}{l}\text { Basal IGFBP-2 } \\
\text { ng/ml }\end{array}$ \\
\hline 1 & 11 & 1.0 & $357(132-376)$ & 463 & $3.2(2.0-4.8)$ & 112 & $199(200-470)$ \\
2 & 4 & 0.76 & $218(54-178)$ & 433 & $1.6(0.8-3.0)$ & 136 & $220(275-700)$ \\
3 & 8 & 1.2 & $181(113-261)$ & 539 & $2.5(2.1-4.2)$ & 72 & $384(255-540)$ \\
4 & 10 & 0.92 & $100(140-308)$ & 249 & $2.6(2.0-4.8)$ & 38 & $704(200-470)$ \\
5 & 3 & 0.85 & $66(54-178)$ & 190 & $1.8(0.8-3.0)$ & 37 & $337(275-700)$ \\
6 & $1 \mathrm{mo}$ & 0.37 & $45(15-109)$ & 167 & $1.8(0.3-1.4)$ & 25 & $785(348-922)$ \\
7 & 7 mo & 0.45 & $38(7-93)$ & 241 & $1.9(1.0-2.3)$ & 20 & n.d. (348-922) \\
\hline
\end{tabular}

$\mathrm{BSA}=$ Body surface area; $\mathrm{BMI}=$ body mass index $\mathrm{F}=$ female; $\mathrm{M}=$ male. Normative ranges in parentheses courtesy of Esoterix Endocrinology (Calabasas Hills, Calif., USA). n.d. = Not determined. Patients 4 and 7 received octreotide as described in Methods.

\section{Statistical Analysis}

Mean serum IGF and IGFBP levels at baseline (prior to rhIGFI administration) and during rhIGF-I trial were analyzed by MannWhitney U test (InStat ${ }^{\mathrm{TM}}$ for Macintosh ${ }^{\circledR}$, version 2.00; GraphPad Software, San Diego, Calif., USA). Basal control values were obtained prior to administration of rhIGF-I to eliminate possible confounding effects of prior exposure to the drug. Peak IGF-I levels were defined as the maximal level of IGF-I achieved by $12 \mathrm{~h}$ after the initial $40 \mu \mathrm{g} / \mathrm{kg}$ dose of rhIGF-I. Pearson linear correlation coefficients (r) were calculated to compare relationships between peak IGF-I to body weight, BSA, and levels of each IGFBP. Data are displayed as means \pm SE. All probability values (p) are two-tailed, and values $<5 \%$ were considered significant.

\section{Results}

Details of the study group are outlined in table 1, and genotyping of patients 1-4 has been previously reported [14]. These 4 children were homozygous for the common
SUR1 mutations, known to account for approximately $88 \%$ of the HI alleles identified in affected Ashkenazi Jewish patients [25]. Patients 5-7 lacked identified SURI or Kir6. 2 mutations [26], but were clinically unresponsive to diazoxide, a medication that acts via the SUR1. Basal serum IGF-I levels were measured at time 0 just prior to administration of the initial $40 \mu \mathrm{g} / \mathrm{kg}$ dose of rhIGF-I, administered subcutaneously at time $0,12 \mathrm{~h}$, and $24 \mathrm{~h}$.

Following the initial rhIGF-I dose, mean serum total IGF-I levels rose rapidly from baseline by $56 \%$ at $30 \mathrm{~min}$ $(\mathrm{p}<0.01$ ) and by $85 \%$ at $120 \mathrm{~min}$ (fig. $1 \mathrm{~A} ; \mathrm{p}<0.02$ ) (fig. 1A, table 2). Following the initial dose, mean peak serum IGF-I levels were achieved within $2-5 \mathrm{~h}$ after the initial dose of rhIGF-I. These peak values were more than double the basal serum IGF-I levels: $373 \pm 67$ vs. $174 \pm$ $49 \mathrm{mg} / \mathrm{dl}(\mathrm{p}<0.04)$. [For patient 4 , the $12 \mathrm{~h}$ value was used in the peak value analysis, as no $2-5 \mathrm{~h}$ value was available due to phlebotomy limits.] Peak serum IGF-I 


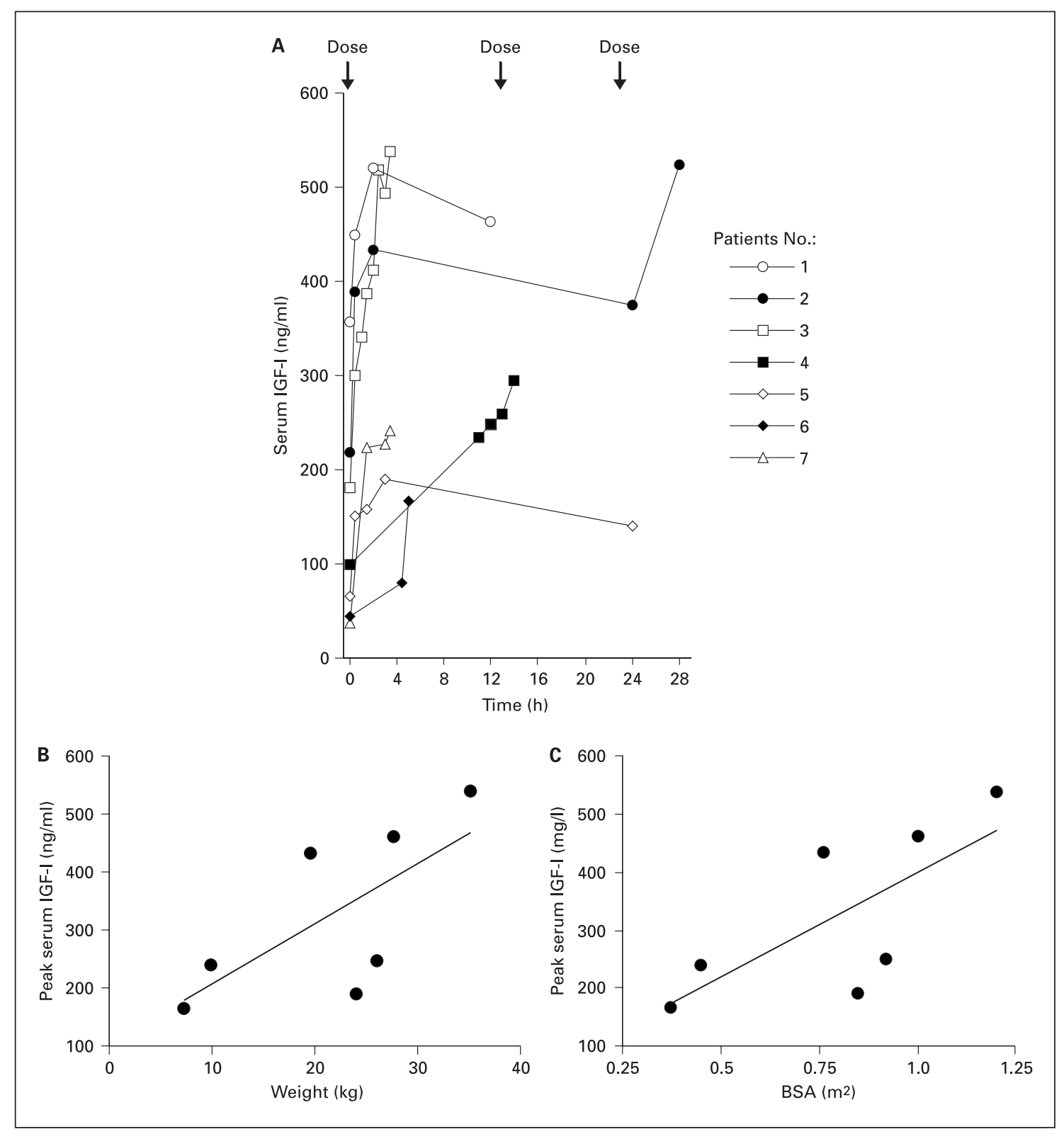

Fig. 1. A Changes in total serum IGF-I levels from baseline (time 0 ) in 7 children treated with $40 \mu \mathrm{g} / \mathrm{kg}$ rhIGF-I s.c. at time 0,12 , and $24 \mathrm{~h}$. B, C Peak serum IGF-I levels of each patient by $12 \mathrm{~h}$ after the first dose of rhIGF-I $(40 \mu \mathrm{g} / \mathrm{kg}$ s.c. $)$ vs. body weight $(\mathrm{r}=0.84 ; \mathrm{p}<0.009)(\mathbf{B})$ and vs. BSA $(\mathrm{r}=0.87 ; \mathrm{p}<0.006)(\mathbf{C})$.

levels achieved at $2-5 \mathrm{~h}$ after the initial $40 \mu \mathrm{g} / \mathrm{kg}$ dose of rhIGF-I directly correlated with weight $(\mathrm{r}=0.84$; $\mathrm{p}<$ 0.009; fig. 1B) and BSA ( $\mathrm{r}=0.87$; $\mathrm{p}<0.006$; fig. $1 \mathrm{C})$.

Mean serum IGF-II, IGFBP-2, and IGFBP-3 levels did not change significantly during the three-dose rhIGF-I treatment, although serum IGF-II levels trended lower in all subjects and serum IGFBP-3 levels trended higher in most subjects (data not shown). Correlations of peak IGF-I levels with baseline serum IGFBP-2 or IGFBP-3 levels did not reach statistical significance: $-0.75(\mathrm{p} \leq 0.053)$ and $+0.65(\mathrm{p}<0.08)$. Fasting serum IGFBP-1 levels in this cohort have been previously reported [14] and did not change significantly on rhIGF-I, consistent with our previous data showing suppression of IGFBP-1 in hyperinsulinism during fasting [27]. 


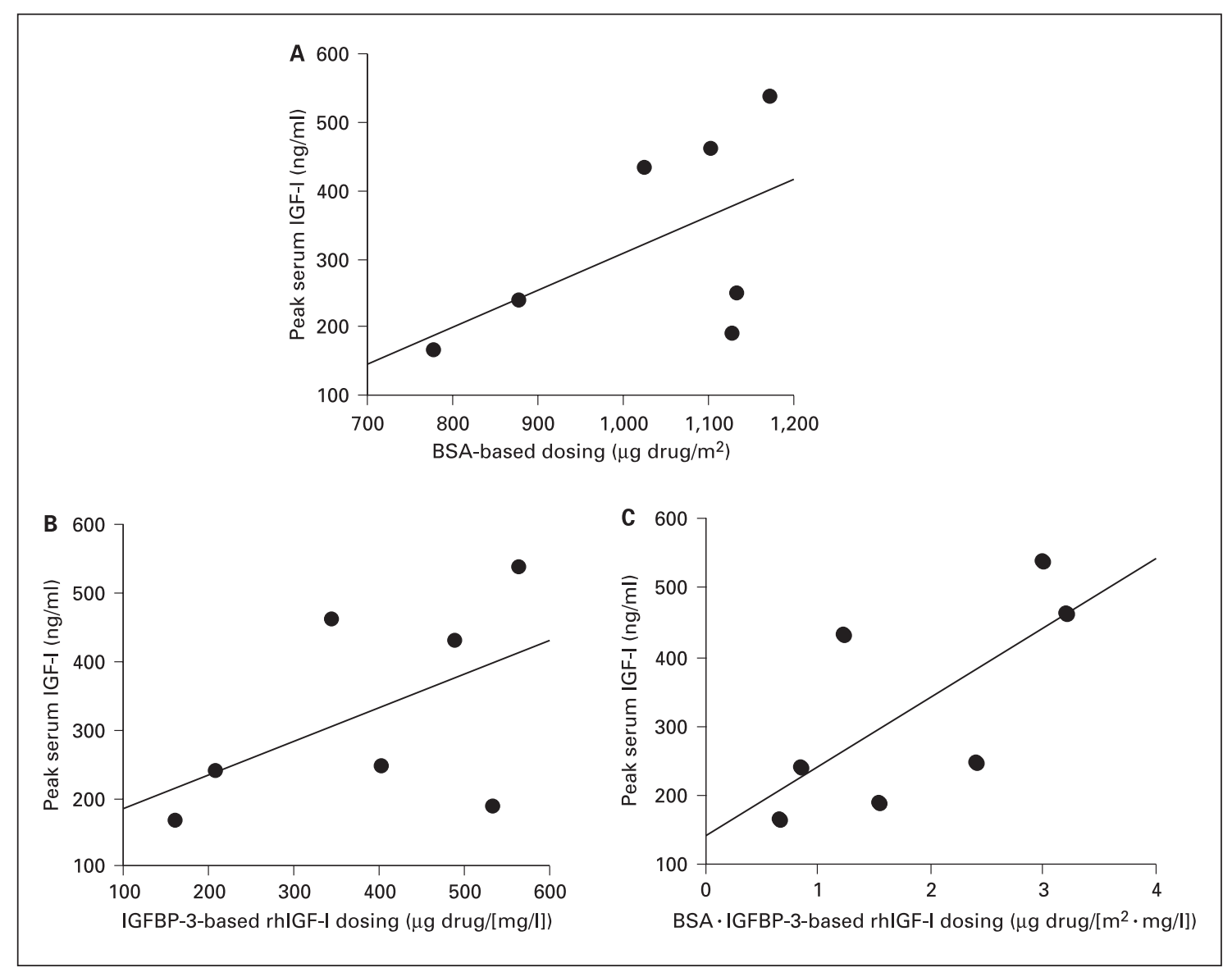

Fig. 2. Actual peak serum IGF-I levels after a single rhIGF-I dose based on BSA $(r=0.78 ; p<0.03)(\mathbf{A})$, initial serum IGFBP-3 concentration $(\mathrm{r}=0.78 ; \mathrm{p}<0.03)(\mathbf{B})$, or the product of BSA and initial IGFBP-3 concentration $(\mathrm{r}=0.85 ; \mathrm{p}<0.007)(\mathbf{C})$.

The range of peak serum IGF-I levels achieved varied widely across the patient group following the initial weight-based dose: $167-700 \mathrm{ng} / \mathrm{ml}$. All children had received the same dose of rhIGF-I based on body weight regardless of age: $40 \mu \mathrm{g} / \mathrm{kg} /$ dose. We modeled the rhIGF-I dose administered based upon BSA, the baseline serum IGFBP-3 level, or the product of BSA and IGFBP-3 level (BSA-IGFBP-3). BSA-based dosing resulted in predictable peak serum IGF-I levels $(r=0.78$; $\mathrm{p}<0.03$; fig. 2A). Dosing based upon the initial serum IGFBP-3 level was equally predictive of peak IGF-I levels as BSA-based dosing $(\mathrm{r}=0.78 ; \mathrm{p}<0.03$; fig. 2B). rhIGF-I dosing based upon the BSA $\cdot$ IGFBP-3 product yielded the closest relationship with the highest $r$ value: $r=0.85(p<$ 0.007; fig. 2C). Basal serum IGF-I levels were also correlated to $\mathrm{BSA}$ and to the $\mathrm{BSA} \cdot \mathrm{IGFBP}-3$ product, $\mathrm{r}=0.6$ and 0.7 , respectively.

\section{Discussion}

We have presented the effects of prospective rhIGF-I administration in a unique pediatric cohort. In fasting healthy volunteers, rhIGF-I has been shown to lower blood glucose levels through its direct insulin-like action on muscle, liver and other tissues. Decreased serum blood glucose levels result in lower insulin release from pancreatic $\beta$-cells. Conversely, prior trials in adults with GHIS [28-30] as well as in children with GHIS [3] have an associated increase in serum glucose levels during rhIGF-I therapy due to suppression of insulin release. Despite suppression of insulin release by rhIGF-I treatment in our group of children with congenital hyperinsulinism, we observed lack of clinical improvement in fasting tolerance in this trial [14]. This observation may have resulted in part from insulin-like actions caused by the binding of free rhIGF-I to type 1 IGF or hybrid IGF-insulin receptors. 
Using the conventional dosing regimen for rhIGF-I based on weight alone, we observed unpredictable acute serum IGF-I concentrations in these children (fig. 1). Mean peak serum IGF-I levels after a $40 \mu \mathrm{g} / \mathrm{kg}$ dose s.c. of rhIGF-I rose at least twofold above basal in our children. Total IGF levels rose rapidly after s.c. administration, while serum IGFBP levels did not change. Thus, serum IGFBP levels and tissue binding sites may have been insufficient to buffer against the rapid elevations of the free serum IGF-I levels of these children.

We did not observe significant, acute changes in levels of the major serum IGFBPs $(-1,-2$ and -3$)$ to account for the unpredictable rise in total IGF-I levels. Serum IGFBP-2 and -3 levels remained within normal ranges, despite supraphysiologic serum IGF-I levels during rhIGF-I administration. Normal developmental differences in basal serum IGFBP-3 concentrations [31-33] across the age range studied (1 month to 11 years) may have been contributed significantly to the observed variability in IGF pharmacokinetics in our pediatric trial. The lack of change in serum IGFBP-3 levels with acute rhIGF-I treatment in our prepubertal children is consistent with prior trials in children with GHIS $[34,35]$ or severe insulin resistance [36]. Although only 2 patients in our study received octreotide, which may suppress $\mathrm{GH}$ production and hence all GH-related peptides, this commonly used therapy for congenital hyperinsulinism renders less interpretable the changes in serum IGFBP levels observed during rhIGF-I administration to these patients. We included these patients in our analysis because their responses were similar to the other patients and did not alter the data analysis. A larger cohort, if available, would allow comparison of patients with and without octreotide therapy.

Other trials have reported changes in serum IGFBP levels. In patients with complete GHIS, rhIGF-I has been shown to increase serum IGFBP-2 levels [4]. Serum IGFBP-3 levels in type 1 diabetic patients rose after a single, subcutaneous dose of rhIGF-I [37, 38]. In patients with GHIS [39], chronic rhIGF-I administration has been associated with a drop in serum IGFBP-3 levels. In patients with complete GHIS, rhIGF-I has also been shown to suppress serum IGF-II levels [4]. We did not observe a significant drop in serum IGF-II levels over the 28-hour time course despite a simultaneous rise in free IGF-I levels. rhIGF-I appeared to displace IGF-II from serum IGFBPs, which would likely increase IGF-II clearance.

Euglycemic clamp studies of adults with type 1 diabetes demonstrate that rhIGF-I suppressed overnight GH secretion [20]. Due to phlebotomy limits, we did not assess whether acute suppression of $\mathrm{GH}$ occurred in our patients. Of note, octreotide therapy (received by patients 4 and 7) may suppress GH levels.

What is the ideal basis for rhIGF-I dosing in children? The goal of any dosing regimen is to achieve desired therapeutic effects safely and predictably. Factors determining free IGF concentrations include the administered rhIGFI dose, route of administration, total IGF binding affinity by serum and tissue IGFBPs, uptake/degradation by tissue IGF receptors, and rates of hepatic, renal, and proteolytic elimination. Several investigators have proposed that bound IGF-I exerts greater biological actions than free IGF-I [40-42]. Compared to adults, children experience developmental changes in body mass and have increased surface area/volume ratio and relatively smaller intravascular volume [43]. These differences in physiology profoundly affect clinical pharmacology in the pediatric population, and conventional dosing based on weight alone is a rough surrogate for these developmental parameters.

Dosing based on BSA permits more accurate estimation of the volume of distribution. For many drugs, pharmacodynamics based on BSA dosing is superior to weightbased dosing [44]. Total serum IGF-I and IGFBP-3 levels rise with age in normal prepubertal children. The widest pediatric experience with IGF dosing has been seen in patients with complete GHIS or poorly controlled type 1 diabetes. Such patients typically manifest profound perturbations in serum ALS and IGFBP profiles, which in turn affect many rhIGF-I pharmacokinetics [45]. In our trial, in which serum binding proteins significantly regulate free drug bioavailability, and where binding protein concentrations change significantly over time, drug dosing based upon the serum binding protein concentration appears to yield more predictable pharmacokinetics. Others have also suggested that IGFBP-3 levels modulate IGF-I kinetics [46, 47]. In addition, IGF-I treatment in Rabson-Mendalhall syndrome was associated with reduced IGF-I kinetics probably due to low IGFBP-3 [48].

Infants typically demonstrate low serum ALS levels; perhaps low IGFBP-3 and IGF-I levels are at least as anabolic in infants as in older children with higher ALS, IGFBP-3, and IGF-I levels. We present no data to address the relative, endogenous IGF-I production, but it may be similar when normalized per kilogram of body weight. A lower peak IGF-I level in serum may be sufficient to support anabolism in the young child, but not in the older child. Our proposed dosing regimen based on BSA and IGFBP-3 may yield similar total IGF-I levels; thus, this regimen may lead to large differences in the biological response. It behooves pediatricians to adjust rhIGF-I dosing by monitoring the serum IGF-I and IGFBP-3 levels 
to ensure these levels remain in the physiologic ranges, adjusted for age and Tanner stage. We could not address this particular safety issue in the relatively brief time course of this study.

In this trial, BSA and baseline IGFBP-3 concentrations were good predictors of the acute rhIGF-I rise. The BSA . IGFBP-3 product demonstrated the highest $r$ value for predicting rhIGF-I pharmacokinetics. Since rhIGF-I is now under development for a more diverse set of indications, including primary IGF-I deficiency associated with short stature as well as for hyperglycemic syndromes, dosing and monitoring strategies are essential for the optimization of rhIGF-I therapy. Our findings suggest that a more individualized regimen for initial dosing should consider the baseline IGFBP-3 level. In addition, monitoring serum IGF-I levels and adjusting dose to achieve age- and gender-appropriate IGF-I levels (serum peak and trough) should improve the safety and efficacy profiles of this emerging new therapeutic modality. The optimal rhIGF-I dose will depend upon the clinical condition being treated and the clinical outcome desired, such as linear growth for GHIS vs. suppression of insulin oversecretion for congenital HI. Figure 2C provides the simple nomogram for initial rhIGF-I dosing in prepubertal children.

In conclusion, we observed individual variability in IGF-I levels achieved on a weight-based IGF-I dosing regimen in this pediatric cohort with hyperinsulinism, in the absence of acute changes in serum IGFBP or IGF-II lev- els. Such pharmacokinetic unpredictability underscores the need to tailor drug therapy to each individual child's IGF physiology. This is one of the few trials of rhIGF-I administered to a pediatric population with normal IGFBP-3 levels over a wide age range. Our study supports the concept of BSA alone or in conjunction with baseline serum IGFBP-3 levels as a novel basis for initial rhIGF-I dosing in children. Our pediatric IGF-I dosing model is limited by its short time course and phlebotomy sampling limitations in these young children due to glycemic instability of HI and limited venous access. Future studies should examine the effects of various modes of administration (s.c. vs. i.v.) and compare steady-state free IGF pharmacokinetics with dosing based on anthropometrics and IGFBP-3. Future pharmacokinetic studies during rhIGF-I administration in children should verify the efficacy of the novel BSA-IGFBP-3-based dosing model while incorporating therapeutic drug monitoring with levels of free IGF-I, IGFBP-3, ALS, and GH in serum.

\section{Acknowledgements}

This work was supported in part by NIH grants(MO1-RR00240, K08 DK02876 to R.F., Clinical Associate Physician Award and University of Pennsylvania Diabetes Endocrinology Research Center Grant P30DK19525 to L.K.), an FDA Orphan Products Grant (to P.C.), and the Genentech Clinical Scholar Award of the Lawson Wilkins Pediatric Endocrine Society (to R.F.).

\section{References}

$>1$ Ferry RJ Jr, Cohen P: The insulin-like growth factor axis in pediatrics. Clin Pediatr Endocrinol 1999;8:1-10.

-2 Mauras N, Martinez V, Rini A, Guevara-Aguirre J: Recombinant human insulin-like growth factor I has significant anabolic effects in adults with growth hormone receptor deficiency: Studies on protein, glucose, and lipid metabolism. J Clin Endocrinol Metab 2000;85:30363042.

- 3 Walker JL, Ginalska-Malinowksa M, Romer TE, Pucilowska JB, Underwood LE: Effects of the infusion of insulin-like growth factor I in a child with growth hormone insensitivity (Laron dwarfism). N Engl J Med 1991;324:14831488.

-4 Vaccarello MA, Diamond FB Jr, GuevaraAguirre J, Rosenbloom AL, Fielder PJ, Gargosky S, Cohen P, Wilson K, Rosenfeld RG: Hormonal and metabolic effects and pharmacokinetics of recombinant insulin-like growth factor-I in growth hormone receptor deficiency/Laron syndrome. J Clin Endocrinol Metab 1993; 77:273-280
5 Thrailkill KM, Quattrin T, Baker L, Kuntze JE, Compton PG, Martha PM Jr: Cotherapy with recombinant human insulin-like growth factor I and insulin improves glycemic control in type 1 diabetes. Diabetes Care 1999;22: 585-592.

-6 Crowne EC, Samra JS, Cheetham T, Watts A, Holly JM, Dunger DB: Recombinant human insulin-like growth factor-I abolishes changes in insulin requirements consequent upon growth hormone pulsatility in young adults with type I diabetes mellitus. Metabolism 1998;47:31-38.

-7 Cioffi WG, Gore DC, Rue LW 3rd, Carrougher G, Guler HP, McManus WF, Pruitt BA Jr: Insulin-like growth factor-1 lowers protein oxidation in patients with thermal injury. Ann Surg 1994;220:310-319.

8 Clemmons DR, Smith-Banks A, Underwood LE: Reversal of diet-induced catabolism by infusion of recombinant insulin-like growth factor-I in humans. J Clin Endocrinol Metab 1992; 75:234-238.
-9 Waters D, Danska J, Hardy K, Koster F, Qualls C, Nickell D, Nightingale S, Gesundheit N, Watson D, Schade D: Recombinant human growth hormone, insulin-like growth factor 1 , and combination therapy in AIDS-associated wasting. A randomized, double-blind, placebocontrolled trial. Ann Intern Med 1996;125: 865-872.

10 Herndon DN, Ramzy PI, DebRoy MA, Zheng M, Ferrando AA, Chinkes DL, Barret JP, Wolfe RR, Wolf SE: Muscle protein catabolism after severe burn: effects of IGF-1/IGFBP3 treatment. Ann Surg 1999;229:713-720.

11 Kuzuya H, Matsuura N, Sakamoto M, Makino H, Sakamoto Y, Kadowaki T, Suzuki Y, Kobayashi M, Akazawa Y, Nomura M, et al: Trial of insulin-like growth factor I therapy for patients with extreme insulin resistance syndromes. Diabetes 1993;42:696-705.

12 Vestergaard H, Rossen M, Urhammer SA, Muller J, Pedersen O: Short- and long-term metabolic effects of recombinant human IGFI treatment in patients with severe insulin resistance and diabetes mellitus. Eur J Endocrinol 1997; 136:475-482. 
$\checkmark 13$ Zenobi PD, Glatz Y, Keller A, Graf S, JaeggiGroisman SE, Riesen WF, Schoenle EJ, Froesch ER: Beneficial metabolic effects of insulin-like growth factor I in patients with severe insulin-resistant diabetes type A. Eur J Endocrinol 1994;131:251-257.

14 Katz LEL, Ferry RJ Jr, Stanley CA, CollettSolberg PF, Baker L, Cohen P: Suppression of insulin over-secretion by subcutaneous recombinant human insulin-like growth factor-I in children with congenital hyperinsulinism due to defective $\beta$-cell sulfonylurea receptor. J Clin Endocrinol Metab 1999;84:3117-3124.

-15 Spies M, Wolf SE, Barrow RE, Jeschke MG, Herndon DN: Modulation of types I and II acute phase reactants with insulin-like growth factor-1/binding protein-3 complex in severely burned children. Crit Care Med 2002;30:8388.

16 Underwood LE, Backeljauw P, Duncan V: Effects of insulin-like growth factor I treatment on statural growth, body composition and phenotype of children with growth hormone insensitivity syndrome. GHIS Collaborative Group. Acta Paediatr Suppl 1999;88:182-184.

17 Acerini CL, Harris DA, Matyka KA, Watts AP, Umpleby AM, Russell-Jones DL, Dunger DB: Effects of low-dose recombinant human insulin-like growth factor-I on insulin sensitivity, growth hormone and glucagon levels in young adults with insulin-dependent diabetes mellitus. Metabolism 1998;47:1481-1489.

- 18 Acerini CL, Patton CM, Savage MO, Kernell A, Westphal O, Dunger DB: Randomised placebo-controlled trial of human recombinant insulin-like growth factor I plus intensive insulin therapy in adolescents with insulin-dependent diabetes mellitus. Lancet 1997;350: 1199-1204.

19 Batch JA, Baxter RC, Werther G: Abnormal regulation of insulin-like growth factor binding proteins in adolescents with insulin-dependent diabetes. Clin Endocrinol Metab 1991;73: 964-968.

20 Finegold DN, Stanley CA, Baker L: Glycemic response to glucagon during fasting hypoglycemia: An aid in the diagnosis of hyperinsulinism. J Pediatr 1980;96:257-259.

21 Hussain K, Aynsley-Green A: Management of hyperinsulinism in infancy and childhood. Ann Med 2000;32:544-551.

22 Lovvorn HN 3rd, Nance ML, Ferry RJ Jr, Stolte L, Baker L, O'Neill JA Jr, Schnaufer L, Stanley CA, Adzick NS: Congenital hyperinsulinism and the surgeon: Lessons learned over 35 years. J Pediatr Surg 1999;34:786-793.

-23 Lack JA, Stuart-Taylor ME: Calculation of drug dosage and body surface area of children. Br J Anaesth 1997;78:601-605; erratum in Br J Anaesth 1997;79:268.

24 Briars GL, Bailey BJ: Surface area estimation: Pocket calculator vs. nomogram. Arch Dis Child 1994; 70:246-247.

-25 Nestorowicz A, Wilson BA, Schoor KP, Inoue $\mathrm{H}$, Glaser B, Landau H, Stanley CA, Thornton PS, Clement JP 4th, Bryan J, Aguilar-Bryan L, Permutt MA: Mutations in the sulfonylurea receptor gene are associated with familial hyper- insulinism in Ashkenazi Jews. Hum Mol Genet 1996;5:1813-1822.

26 Thomas P, Ye Y, Lightner E: Mutation of the pancreatic islet inward rectifier Kir6.2 also leads to familial persistent hyperinsulinemic hypoglycemia of infancy. Hum Mol Genet 1996;5:1809-1812.

27 Katz LEL, Satin-Smith MS, Collett-Solberg P, et al: Insulin-like growth factor binding protein-1 levels in the diagnosis of hypoglycemia due to hyperinsulinism. J Pediatr 1997;131: 193-199.

28 Wilton P, Sietnieks A, Gunnarsson R, Berger L, Grahnen A: Pharmacokinetic profile of recombinant human insulin-like growth factor I given subcutaneously in normal subjects. Acta Paediatr Scand 1991;377:111-114.

29 Oscarsson J, Lundstam U, Gustafsson B, Wilton P, Eden S, Wiklund O: Recombinant human insulin-like growth factor-I decreases serum lipoprotein(a) concentrations in normal adult men. Clin Endocrinol 1995;42:673676.

30 Zenobi PD, Graf S, Ursprung H, Froesch ER: Effects of insulin-like growth factor-I on glucose tolerance, insulin levels, and insulin secretion. J Clin Invest 1992;89:1908-1913.

31 Gelander L, Blum WF, Larsson L, Rosberg S, Albertsson-Wikland K: Monthly measurements of insulin-like growth factor I (IGF-I) and IGF-binding protein-3 in healthy prepubertal children: Characterization and relationship with growth: the 1-year growth study. Pediatr Res 1999;45:377-383.

32 Blum WF, Ranke MB: Use of insulin-like growth factor-binding protein 3 for the evaluation of growth disorders. Horm Res 1990;33: 31-37.

- 33 Juul A, Dalgaard P, Blum WF, Bang P, Hall K, Michaelsen KF, Muller J, Skakkebaek NE: Serum levels of insulin-like growth factor (IGF)binding protein-3 (IGFBP-3) in healthy infants, children, and adolescents: The relation to IGF-I, IGF-II, IGFBP-1, IGFBP-2, age, sex, body mass index, and pubertal maturation. $\mathrm{J}$ Clin Endocrinol Metab 1995;80:2534-2542.

-34 Guevara-Aguirre J, Vasconez O, Martinez V, Martinez AL, Rosenbloom AL, Diamond FB Jr, Gargosky SE, Nonoshita L, Rosenfeld RG: A randomized, double-blind, placebo-controlled trial on safety and efficacy of recombinant human insulin-like growth factor-I in children with growth hormone receptor deficiency. J Clin Endocrinol Metab 1995;80:13931398.

35 Ranke MB, Savage MO, Chatelain PG, Preece MA, Rosenfeld RG, Wilton P: Long-term treatment of growth hormone insensitivity syndrome with IGF-I. Results of the European Multicentre Study. The Working Group on Growth Hormone Insensitivity Syndromes. Horm Res 1999;51:128-134.

36 Nakae J, Kato M, Murashita M, Shinohara N, Tajima T, Fujieda K: Long-term effect of recombinant human insulin-like growth factor I on metabolic and growth control in a patient with leprechaunism. J Clin Endocrinol Metab 1998;83:542-549.
-37 Cheetham TD, Holly JM, Baxter RC, Meadows K, Jones J, Taylor AM, Dunger DB: The effects of recombinant human IGF-I administration on concentrations of acid labile subunit, IGF binding protein-3, IGF-I, IGF-II and proteolysis of IGF binding protein-3 in adolescents with insulin-dependent diabetes mellitus. J Endocrinol 1998;157:81-87.

38 Quattrin T, Thrailkill K, Baker L, Kuntze J, Compton $\mathrm{P}$, Martha $\mathrm{P}$, for rhIGF-I in IDDM Study Group: Improvement of HbAlc without increased hypoglycemia in adolescents and young adults with type 1 diabetes mellitus treated with recombinant human insulin-like growth factor-I and insulin. J Pediatr Endocrinol Metab 2001;14:267-277.

- 39 Labarta JI, Gargosky SE, Simpson DM, Lee PD, Argente J, Guevara-Aguirre J, Rosenfeld RG: Immunoblot studies of the acid-labile subunit in biological fluids, normal human serum and in children with GH deficiency and GH receptor deficiency before and after long-term therapy with GH or IGF-I respectively. Clin Endocrinol 1997;47:657-666.

40 Cornell HJ, Enberg G, Herington AC: Preferential association of the insulin-like growth factors I and II with metabolically inactive and active carrier-bound complexes in serum. Biochem J 1987;241:745-750.

41 Adams S, Moore J, Chu S, Bagi C, DeLeon L, Liu C, Schmidt D, Sommer A: Pharmacokinetics and bioavailability of rhIGF-I/IGFBP-3 in the rat and monkey. Prog Growth Factor Res 1995;6:347-356.

42 Lovett-Racke AE, Bittner P, Cross AH, Carlino JA, Racke MK: Regulation of experimental autoimmune encephalomyelitis with insulinlike growth factor (IGF-1) and IGF-1/IGFbinding protein-3 complex (IGF-1/IGFBP3). J Clin Invest 1998;101:1797-1804.

43 Roundtable on Research and Development of Drugs, Biologics, and Medical Devices. Rational Therapeutics for Infants and Children. Washington, National Academy Press, 2000.

44 Gurney H: Dose calculation of anticancer drugs: A review of the current practice and introduction of an alternative. J Clin Oncol 1996;14:2590-2611.

45 Frystyk J, Hussain M, Skjarbak C, Porksen N, Froesch ER, Orskov H: The pharmacokinetics of free insulin-like growth factor-I in healthy subjects. Growth Horm IGF Res 1999;9:150156.

46 Mauras N, Quarmby V, Bloedow DC: Pharmacokinetics of insulin-like growth factor I in hypopituitarism: Correlation with binding proteins. Am J Physiol 1999;277:E579-E584.

47 Laron Z, Klinger B, Silbergeld A: Serum insulin-like growth factor-I (IGF-I) levels during long-term IGF-I treatment of children and adults with primary GH resistance (Laron syndrome). J Pediatr Endocrinol Metab 1999;12: 145-152.

48 Longo N, Singh R, Elsas LJ: Decreased half-life of insulin-like growth factor I in Rabson-Mendelhall syndrome. J Inherit Metab Dis 2001; 24:546-550. 